\title{
THE STRENGTHENING OF TERRITORIAL COHESION THROUGH THE DEVELOPMENT OF RURAL SOCIAL INFRA- STRUCTURE
}

\author{
Vilma AtKočiuniene ${ }^{1}$, Alvydas Aleksandravičius² ${ }^{2}$, Gunta Grinberga-Zalite ${ }^{3}$ \\ Aleksandras Stulginskis University (Lithuania), Latvia University of Agriculture (Latvia)
}

\begin{abstract}
Economic and social indicators need to be given more importance in the management of results-oriented rural social infrastructure (RSI) in order to become an integral measure in the monitoring of country's development. The research aim - to prepare and test a methodology for the assessment of RSI condition in order to ensure the territorial cohesion. The following objectives have been set out: 1) to summarize theoretical aspects of rural social infrastructure development in the context of social territorial cohesion; 2) to prepare a methodology for the assessment of RSI; 3) to reveal inequalities and critical areas of Lithuanian RSI development. The analysis of Lithuanian RSI data revealed differences in RSI development in different rural regions which negatively affect Lithuania's competitiveness and social territorial cohesion. While the articles notes that there have been some positive changes in the use of investment projects over the last couple of years, it also indicates that management of RSI availability and accessibility with respect to locations and sectors is not optimal.
\end{abstract}

KEY WORDS: rural social infrastructure, rural areas, territorial cohesion.

JEL CODES: H410, O330, R530, R590.

\section{Introduction}

Half of Europe, which is home to around 20 percent of Europe's population, consists of rural areas. The number is even greater in Eastern Europe. In the 2010's they face various challenges created by migration and modernization processes which directly affect the development of rural social infrastructure (RSI):

1 Vilma Atkočiūnienè - doctor of social sciences, Aleksandras Stulginskis University, Faculty of Economics and Management, professor of Business and Rural Development Management. Scientific interests: rural communities development, rural regional development, development of rural social infrastructure, local marketing, social partnership

Address: Universiteto Str. 10, LT-4324 Kaunas-Akademija, Kauno r.

E-mail: vilma.atkociuniene@gmail.com

Tel. +3707752214

2 Alvydas Aleksandravicius - lector of Aleksandras Stulginskis University, Faculty of Economics and Management, Institute of Business and Rural Development

Address: Universiteto Str. 10, LT-53361 Akademija, Kauno r.

E-mail: aleksandravicius@gmail.com

Tel. +370 377522 36; +37061434220

3 Gunta Grinberga-Zalite - doctor of social sciences, Latvia University of Agriculture, Faculty of Economics and Social Development, associate professor of Regional Economics. Scientific interests: social marketing, social innovation, regional development.

Address: Svetes 18, Jelgava, LV-3001 Latvia

E-mail: gunta.grinberga@1lu.lv

Tel. +37129463545 
maintaining social infrastructure (SI) objects in rural areas become expensive due to decreasing population, RSI services supply needs to be coordinated with their demand by ensuring their availability and accessibility, RSI functioning requires large investments and good governance models.

Methods applied to change management of rural areas and activity methods of RSI objects change, whereas RSI development level and functions are usually different in each country due to geography, strategic decisions or the national and cohesion policies implemented. One thing common to the entire EU though is that rural areas mainly differ in GDP per capita. However, from the economic perspective, rural areas should not be considered as declining. They face challenges which are also relevant in the areas defined by the CAP, the cohesion policy, and also sectoral policies in such areas as culture, education, social security, and transportation. As of the beginning of the 1990s when the number of EU member states started increasing quickly, the issue of territorial social cohesion as a way to increase territorial competitiveness has become more and more urgent.

Both scholars (Swanson, 1992, 1996; Sharp et al., 2002; Péti, 2012; Zitkus, Mickeviciene, 2013) and practitioners (Hübner, 2007; EU..., 2007; CEC, 2008; Barca, 2009) agree that the essential condition for promoting social and economic development in rural areas is to thoroughly improve infrastructure according to sustainable development principles. Scholars who provide definitions of social infrastructure (Flora, Flora, 1993; Swanson, 1992; 1996; Atkociuniene, 2000; 2008; 2014; Atkociuniene, Kiausiene, Urmoniene, 2014) note that RSI has a hierarchical organizational structure, the operating area of RSI objects is rural and urban regions, and that RSI is one of the components that contribute to region's competitiveness.

The article tries to provide a solution to a scientific problem on how to assess the RSI condition and what causes inequalities in the development of RSI as a contributor to the rural area competitiveness. The research assumes that assessment of RSI is a suitable method for revealing territorial cohesion: an integrated RSI condition indicator shows unequal territorial development of a country, the concentration of social infrastructure services in major cities or regional centres, and the centralization of RSI as a solution to developmental issues.

The research object is rural social infrastructure.

The research aim - to prepare and test a methodology for the assessment of the condition of RSI in order to ensure the territorial cohesion.

The following objectives have been set out: 1) To summarize theoretical aspects of rural social infrastructure development in the context of territorial cohesion; 2) To prepare a methodology for the assessment of RSI; 3) To reveal inequalities and critical areas of Lithuanian RSI development.

\section{Results and Discussion}

L.E. Swanson (1992) conceptualizes social infrastructure as having three parts:

- social institutions in a community such as local government, social service institutions and voluntary organizations (churches, civic, recreational and political associations, etc.);

- human resources, which include attributes of inhabitants such as their technical expertise, organizational skills, educational levels, and the social structure - ethnicity, race and cultural qualities, gender and so on.;

- characteristics of social networks in the community, including innovativeness, ability to mobilize resources within the community, ability to link up with outside expertise and information, and so on.

Later L.E. Swanson (1996) defines social infrastructure in terms of a community's capacity, including decision - making, leadership, organizational and social service capacity. Flora, Flora (1993) define social infrastructure as the "group-level, interactive aspect of organizations or institutions. Three dimensions of social infrastructure are identified: diversity of symbols, resource mobilization and quality of linkages. The resource mobilization dimension includes citizens' willingness to invest in the locality and the capacity of organisations to mobilize resources from both public and private sources. The quality of internal and extra-local linkages is expected to enhance the flow of information, money, and support within and into the 
community (Sharp et al., 2002). RSI can still be seen as a part of the economy in relation to human needs and values, as well as with use of services, and that it is not a mechanical amount of the different economic activities, objects, but their complex, where all elements must be of adequate size, optimally placed to give good enough results (Atkociuniene, 2000; 2008).

RSI development is a formation of strong societies through the ongoing territorial development and public engagement activities, allocation of resources, enhancement of competences and trustworthiness of human society groups, empowering them to take effective actions and take up dominant attitude. While creating strong rural society, the abovementioned description shall be complemented in terms of service availability and accessibility, and the RSI development target itself should be considered. J.S Sharp et al. (2002) findings suggest that improving social capacity will benefit self-development undertakings more so than industrial recruitment efforts. Improving social infrastructure in a policy environment biased toward industrial recruitment may not optimally use local social infrastructure or achieve maximum development results. The challenge for communities is that building social infrastructure as well as achieving success at self-development may be a long-term process and not necessarily an easy one, particularly for communities with limited resources. RSI addressing individual and social needs not only ensure the smooth development of rural areas and rural basic functions, but may become important factor strengthening the competitiveness in rural areas or component of competitiveness. Value of RSI in achieving territorial cohesion is high (Atkociuniene, 2014).

Cohesion processes are seen as having particular importance in the current phase of European Union development and expansion, as they represent the general internal integration trend which is common to different EU regions, especially those with small countries or those which appear in the junction amongst multiple countries.

While managing regional development process long time dominated classical paradigm of territorial cohesion is changing (Zitkus, Mickeviciene, 2013), i.e. from regional and local reduce of development disparities, it is being moved to territorial competitiveness enhancement. Regional development objectives dilemma has been raised - equality or competitiveness. While supporting classical territorial cohesion, limiting the possibility of increasing the competitiveness of the regions and on the contrary - while promoting territorial competitiveness raises the polarization of regional development. Therefore, the internal cohesion of regions and regional competitiveness problem of compatibility is not sufficiently explored at the theoretical level.

The Green Paper on Territorial Cohesion (Hübner, 2007) points out that territorial cohesion affects territorial competitiveness, societal well-being and environmental quality. The idea of territorial cohesion raises a question - what is the most efficient way to utilize the unique and highly diverse European settlement structure so that European citizens do not become disadvantaged in terms of employment opportunities, living conditions, their access to public services, etc. just because they live in a certain region. It is necessary to ensure more balanced and more sustainable development which increases competitiveness, while at the same time preserving such natural resources as open rural areas. Such development should ensure social cohesion (Hübner, 2007).

The term of territorial cohesion has been introduced into the development policies of the EU in the early - and mid-1990s (Faludi, 2004). Then, it became an official shared competency between the Union and the EU member states by signing the Lisbon Treaty in 2007 (EU, 2007). Still there is no clear definition of this term, the European Commission's Green Paper on Territorial Cohesion (CEC, 2008) does not set up a normative understanding (Faludi, 2009). Therefore, the EU member states can create their own territorial cohesion goals and practices. Four discursive categories of the territorial cohesion objectives were defined by Loris Servillo (2010): principles, territorial dimensions, strategic policy options, and aspects of territorial governance. Gareth Abrahams (2014) have called for a pragmatic approach based around questions such as, what does this concept "do" and what "might" it do?

This sustainability-related approach to territorial cohesion is not standalone. Camagni (2007 in EEA (2010)) claims that "territorial cohesion has been defined as being the spatial representation of sustainability (which is time-oriented), since both territorial cohesion and sustainability represent an integration of people, 
planet and profit". The Green Paper on Territorial Cohesion (CEC, 2008) also refers to territorial cohesion as "putting sustainable development at the heart of policy design".

Michel Barnier, European Commissioner for Regional Policy during 2002-2004, initiated a discussion on territorial cohesion and pointed out several of its aspects: equality (i.e. one's birthplace should not become an inevitable determinant of one's opportunities or life quality); competitiveness (regions and areas should essentially contribute to the achievement of growth and job creation goals according to their capabilities); sustainability and good governance. These aspects represent very different and potentially conflicting approaches, each of which needs to be specified and, likely, brought together by evaluating each case individually.

Thus, territorial cohesion is only an invitation for action rather than the outcome in itself. In terms of RSI management, sectorial policy areas should be coordinated with each other, with a stronger focus on the territorial distribution of social and economic inequalities and regional characteristics, which could be used effectively in order to reduce gaps in development.

The traditional territorial policy approach focusing first of all on the economically less developed regions shall be diversified by the spatial integration of sector interventions (CEC, 2010) and by using a so called "place-based approach" (Barca, 2009). This urges to adapt the development interventions to the unique conditions of the different places (settlements, regions), and to spatially harmonize the conflicting development ideas of sustainability and competitiveness. According to Loris Servillo (2010) these "discourses act as cultural constructions which define the strategic selectivity of EU institutions and strategically orientate the selective calculation of stakeholders' behavior and their policy-making activities".

The impact of RSI to rural regions territorial cohesion was portrayed in logical model (Figures 1).

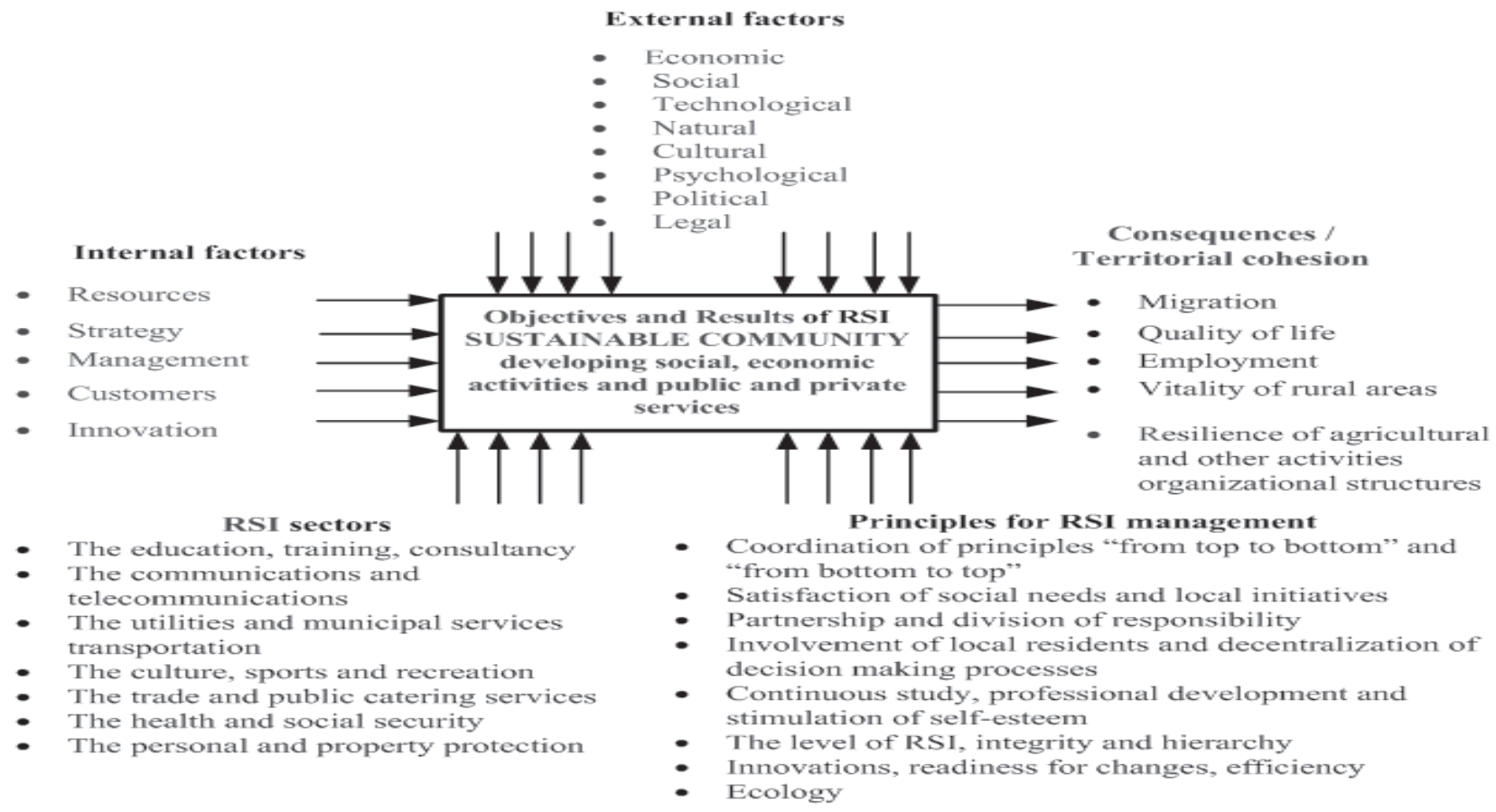

Fig. 1. The Logical Model of Impact of Rural Social Infrastructure Development to Territorial Cohesion of Rural Regions

Source: compiled by the authors

In short, we could argue that the Lisbon Treaty explicitly links the idea of public services with territorial cohesion which is the main aspect of creating territorial cohesion. When assessing cohesion in territorial perspective, sustainable development and access to services become important topics. Between principles 
of RSI management there is no subsidiarity "that subsidiarity, enforcing the assumption that territorial representation within jurisdictions as closely as possible to citizens is the royal road to achieving legitimacy as it does, is in fact a stumbling block. In working to maintain the existing nested hierarchy, supporting an illusionary view of governance in boxes, the territorialism underlying subsidiarity turns it into a conservative principle in the way of achieving real territorial cohesion" (Faludi, 2013).

\section{Methodology and rural social infrastructure assessment}

Despite attempts to accommodate different contextual understandings of territorial cohesion, these research have maintained the essentialist belief that a concept can be defined according to a set of coherent, essential traits and these traits can be used as the basis for measurement and assessment tools.

The research methods are the survey and the analysis of the scientific literature, scientific literature systemization, matching and comparison, multiple-criteria statistical data analyses and syntheses, expert evaluation, graphical representation, and other methods. The selection of indicators for the assessment of RSI in order to ensure territorial cohesion was based on an expert survey whose aim was to justify the importance of sectors and indicators for the assessment of the RSI condition.

The eight sectors were identified for the assessment of the RSI condition in order to ensure territorial cohesion: 1) education, training, consultancy $\left.\left(\mathrm{S}_{1}\right) ; 2\right)$ communications and telecommunications $\left.\left(\mathrm{S}_{2}\right) ; 3\right)$ utilities and municipal services $\left.\left(\mathrm{S}_{3}\right) ; 4\right)$ transportation $\left.\left(\mathrm{S}_{4}\right) ; 5\right)$ culture, sports and recreation $\left.\left(\mathrm{S}_{5}\right) ; 6\right)$ trade and public catering services $\left.\left(\mathrm{S}_{6}\right) ; 7\right)$ health and social security $\left.\left(\mathrm{S}_{7}\right), 8\right)$ personal and property protection $\left(\mathrm{S}_{8}\right)$. Each sector was assigned respective indicators.

The expert survey was carried out by emailing questionnaires to the experts. A total of 55 invitations to participate in the survey were sent out. 23 out of them were accepted. The experts were selected according to their qualification (research and professional activities related to the issues of RSI management) and experience (average experience - more than 20 years).

The experts assessed the indicators by ranking them in the order of importance. The responses received from the experts were analysed on the basis of average response significance. The weighting of each indicator $\left(\mathrm{K}_{\mathrm{sv}}\right)$ was calculated according to the following formula:

$$
K_{s v .}=\frac{\overline{V_{1}}}{\sum_{i=1}^{n} \bar{V}}
$$

Where:

$$
\begin{aligned}
& \bar{V}_{1}-\text { statistical average; } \\
& \sum_{i=1}^{n} \bar{V} \\
& - \text { the sum of statistical averages. }
\end{aligned}
$$

Several limitations emerged when making the list of indicators reflecting the RSI condition. During the selection we took note of comments made by the experts, specialists of Statistics Lithuania, under the Ministry of the Interior, etc., which meant that some of the indicators were adjusted.

Overall, as a general trend, indicators which reflected the difficult current situation of RSI in Lithuania and showed urgent developmental issues in rural areas were selected by the experts as being very significant. Some of the indicators were dropped when assessing the RSI condition later on due to insufficient statistical data on the municipality level. The final list includes indicators which the experts thought were the most important ones, including up to 5 indicators in each sector (Table 1). 
Table 1. Indicators selected for the assessment of the condition of rural social infrastructure in order to ensure territorial cohesion

\begin{tabular}{|c|c|c|}
\hline Sector & Indicator & $\begin{array}{c}\text { Indicator's } \\
\text { weight }\end{array}$ \\
\hline \multirow{5}{*}{$\begin{array}{l}\text { Education, Training, } \\
\text { Consultancy } \\
\left(S_{1}\right)\end{array}$} & Number of general education schools per $1000 \operatorname{residents}\left(S_{1} r_{1}\right)$ & 0.1761 \\
\hline & Number of students per teacher $\left(S_{1} r_{3}\right)$ & 0.1678 \\
\hline & Percentage of pre-school children attending pre-school $\left(S_{1} r_{4}\right)$ & 0.1706 \\
\hline & Number of pre-school children not attending pre-school $\left(S_{1} r_{5}\right)$ & 0.1720 \\
\hline & $\begin{array}{l}\text { Percentage ratio between rural population with higher education and } \\
\text { secondary education }\left(S_{1} r_{6}\right)\end{array}$ & 0.1692 \\
\hline \multirow{3}{*}{$\begin{array}{l}\text { Communications and } \\
\text { Telecommunications } \\
\left(S_{2}\right)\end{array}$} & Mobile GSM (2G) network coverage, percentage $\left(S_{2} r_{2}\right)$ & 0.1806 \\
\hline & Mobile UMTS (3G) network coverage, percentage $\left(S_{2} r_{3}\right)$ & 0.1749 \\
\hline & Number of post offices per $100 \mathrm{~km}^{2}\left(S_{2} r_{4}\right)$ & 0.1517 \\
\hline \multirow{3}{*}{$\begin{array}{l}\text { Utilities and Municipal } \\
\text { Services } \\
\left(\mathrm{S}_{3}\right)\end{array}$} & Total residential area having water supply, percentage $\left(S_{3} r_{1}\right)$ & 0.2360 \\
\hline & Total residential area having wastewater system, percentage $\left(S_{3} r_{2}\right)$ & 0.2275 \\
\hline & Container sites for recyclables, units $\left(S_{3} r_{3}\right)$ & 0.1952 \\
\hline \multirow{4}{*}{$\begin{array}{l}\text { Transportation } \\
\left(S_{4}\right)\end{array}$} & Local roads density $\mathrm{km} / 100 \mathrm{~km}^{2}\left(S_{4} r_{1}\right)$ & 0.1791 \\
\hline & Length of local roads with improved road surface, $\mathrm{km} .\left(\mathrm{S}_{4} r_{2}\right)$ & 0.1918 \\
\hline & Number of public passenger transport routes $\left(S_{4} r_{5}\right)$ & 0.1580 \\
\hline & Number of personal vehicles per 1000 residents $\left(S_{4} r_{6}\right)$ & 0.1749 \\
\hline \multirow{5}{*}{$\begin{array}{l}\text { Culture, Sports, Recreation } \\
\left(S_{5}\right)\end{array}$} & Number of culture centres per 1000 residents $\left(S_{5} r_{1}\right)$ & 0.1105 \\
\hline & Percentage of population participating in cultural activities $\left(S_{5} r_{3}\right)$ & 0.1189 \\
\hline & $\begin{array}{l}\text { Number of members in art enthusiast collectives per } 1000 \text { residents } \\
\left(S_{5} r_{4}\right)\end{array}$ & 0.1114 \\
\hline & $\begin{array}{l}\text { Number of rural community organizations per } 1000 \text { rural residents } \\
\left(S_{5} r_{6}\right)\end{array}$ & 0.1170 \\
\hline & $\begin{array}{l}\text { Number of library branches in rural areas per } 1000 \text { rural residents } \\
\left(S_{5} r_{8}\right)\end{array}$ & 0.1180 \\
\hline \multirow{2}{*}{$\begin{array}{l}\text { Trade and Public Catering } \\
\text { Services }\left(S_{6}\right)\end{array}$} & Number of retailer enterprises per 1000 residents $\left(S_{6} r_{1}\right)$ & 0.5236 \\
\hline & Number of public catering enterprises per 1000 residents $\left(S_{6} r_{2}\right)$ & 0.4764 \\
\hline \multirow{5}{*}{$\begin{array}{l}\text { Health and Social Security } \\
\left(S_{7}\right)\end{array}$} & $\begin{array}{l}\text { Number of health care facilities (outpatient clinics, hospitals, } \\
\text { medical stations) per } 1000 \text { residents }\left(S_{7} r_{1}\right)\end{array}$ & 0.1127 \\
\hline & $\begin{array}{l}\text { Available places in care facilities for the elderly and the disabled per } \\
1000 \text { residents }\left(S_{7} r_{3}\right)\end{array}$ & 0.1083 \\
\hline & $\begin{array}{l}\text { Number of children who have received services at day care centres } \\
\text { per } 1000 \text { children }\left(S_{7} r_{8}\right)\end{array}$ & 0.0988 \\
\hline & $\begin{array}{l}\text { Number of social workers and volunteers (at day care centres, child } \\
\text { care facilities, adult care facilities) per } 10000 \text { residents }\left(S_{7} r_{9}\right)\end{array}$ & 0.1083 \\
\hline & Number of residents who receive social services at home $\left(S_{7} r_{10}\right)$ & 0.1083 \\
\hline \multirow{3}{*}{$\begin{array}{l}\text { Personal and Property } \\
\text { Protection } \\
\left(S_{8}\right)\end{array}$} & Number of police officers per 100000 residents $\left(S_{8} r_{1}\right)$ & 0.3268 \\
\hline & Percentage of all registered criminal offences solved $\left(S_{8} r_{2}\right)$ & 0.3415 \\
\hline & $\begin{array}{l}\text { Number of Fire and Rescue Department and Detention Advice } \\
\text { Service teams per } 1000 \text { residents }\left(S_{8} r_{3}\right)\end{array}$ & 0.3317 \\
\hline
\end{tabular}

Source: compiled by the authors.

As one can see from information provided in Table 1, the final list of indicators for the assessment of the RSI condition in order to ensure territorial and social cohesion includes 30 indicators in total. Sectors with most indicators included (5 each) were education, training, consultancy $\left(S_{1}\right)$, culture, sports, recreation $\left(S_{5}\right)$, and health and social security $\left(S_{7}\right)$, while sectors with least indicators included (2) were trade and public catering services sector $\left(S_{6}\right)$. Hence, the integrated indicator comprises 8 sectors characterised by 30 indicators. 
The formula for the integrated indicator $\left(I_{K S I}\right)$ is as follows:

$$
I_{K S I}=\sum_{i=1}^{i=30} s \cdot r \cdot m
$$

Where:

$s$ - sector's weight (importance);

$r$ - indicator's weight (importance);

$m$ - Min-Max index calculated according to the following formula:

$$
m=\frac{r_{\text {fakt. }}-r_{\text {min }}}{r_{\max }-r_{\min }}
$$

where

$r_{\text {fakt. }}$ - factual value of the indicator;

$r_{\min }$ and $r_{\max }-$ minimum and maximum value of the indicator

First calculated is the Min-Max index, used to assess the situation of a municipality as compared to the municipalities with the worst and the best situations. The factual value of the indicator is the value of a particular indicator for a particular municipality. A municipality with the lowest indicator has a value closer to 0 , whereas the one with the highest - closer to 1 . A minimum value means that the RSI condition in ensuring territorial cohesion is very poor, whereas a maximum (the best) value shows that RSI condition is very good. In order to properly calculate the integrated RSI indicator, we first need to determine which indicators positively/negatively affect the RSI condition when decreasing/increasing. The initial weight of each sector indicator is calculated by multiplying sector's weight coefficient by indicator's weight coefficient (according to 23 experts). Each relevant sector indicator (1 out of 30) is assigned a percentage weight, calculated by dividing its initial percentage weight by the initial percentage weight of all relevant indicators. After calculating each municipality's $I_{K S I}$, we can then compare the situation with other municipalities and assess the progress of each municipality in the development of RSI.

In order to identify regional characteristics of RSI, municipalities were grouped by each RSI indicator. The length of a grouping characteristic is calculated as the difference between the maximum $\left(x_{\max }\right)$ and the minimum $\left(x_{\min }\right)$ value of a grouping variable (RSI indicator):

$$
D=x_{\text {max }}-x_{\text {min }}
$$

Based on the second level equivalents of Lithuanian Regional Framework and EU Nomenclature of Territorial Units, 5 higher-raking regions, i.e. groups of regions having a different RSI development level, are identified The length of a group interval is calculated according to the formula below:

$$
i=\Delta_{x} / n
$$

Where:

$i$ - length of a grouping interval;

$x$ - length of a grouping characteristic;

$n-$ number of groups.

Assessments of each municipality by each RSI indicator are transferred to an interval scoring system by assigning it a score between 1 and 5 ( 5 being very good, 4 - good; 3 - satisfactory; 2 - bad; 1 - very bad). It allows to compare the municipalities by each RSI sector and to also assess the overall RSI condition of a municipality in order to ensure territorial coherence.

In the case of the scientific problem in question, public services provided by the RSI are a concept which needs to be reapplied to territorial cohesion. This could encourage European and national institutions to review many issues related to public services and gradually move to an evidence-based public policy. 
Public services which mainly benefit local (territorial) municipalities are best organized and provided on this level of national administrative structure. RSI multidimensional assessment methodology was formed and the research on RSI in Lithuania was performed by assessing the RSI condition on the municipality (LAU1) level.

Integrated individual Lithuanian districts and municipalities RSI evaluation indicators comparison leads to the conclusion of the whole development of the RSI system of territorial disparities. Integrated assessment of RSI development level, to ensure territorial cohesion, it is found that none of the Lithuanian rural district and the municipality in which the RSI are very well developed (Table 2).

Table 2. Common Distribution of Lithuanian Municipalities by the average condition of the Rural Social Infrastructure, between 2008 and 2012

\begin{tabular}{|c|c|c|c|c|}
\hline \multirow[b]{2}{*}{ Condition of RSI } & \multirow[b]{2}{*}{ Value of indicator } & \multirow{2}{*}{$\begin{array}{c}\text { Comparison with } \\
\text { Lithuanian average, } \\
\%\end{array}$} & \multicolumn{2}{|c|}{ Municipalities } \\
\hline & & & Number & $\begin{array}{c}\% \text { of total number of } \\
\text { municipalities }\end{array}$ \\
\hline Very good (5) & 0,00 & 0,00 & 0 & 0,00 \\
\hline Good (4) & 3,07 & 118,99 & 2 & 3,92 \\
\hline Satisfactory (3) & 2,72 & 105,43 & 29 & 56,86 \\
\hline Poor (2) & 2,37 & 91,86 & 18 & 35,29 \\
\hline Very poor (1) & 1,89 & 73,26 & 2 & 3,92 \\
\hline Total & 2,58 & & 51 & 100,00 \\
\hline
\end{tabular}

Source: the authors calculations

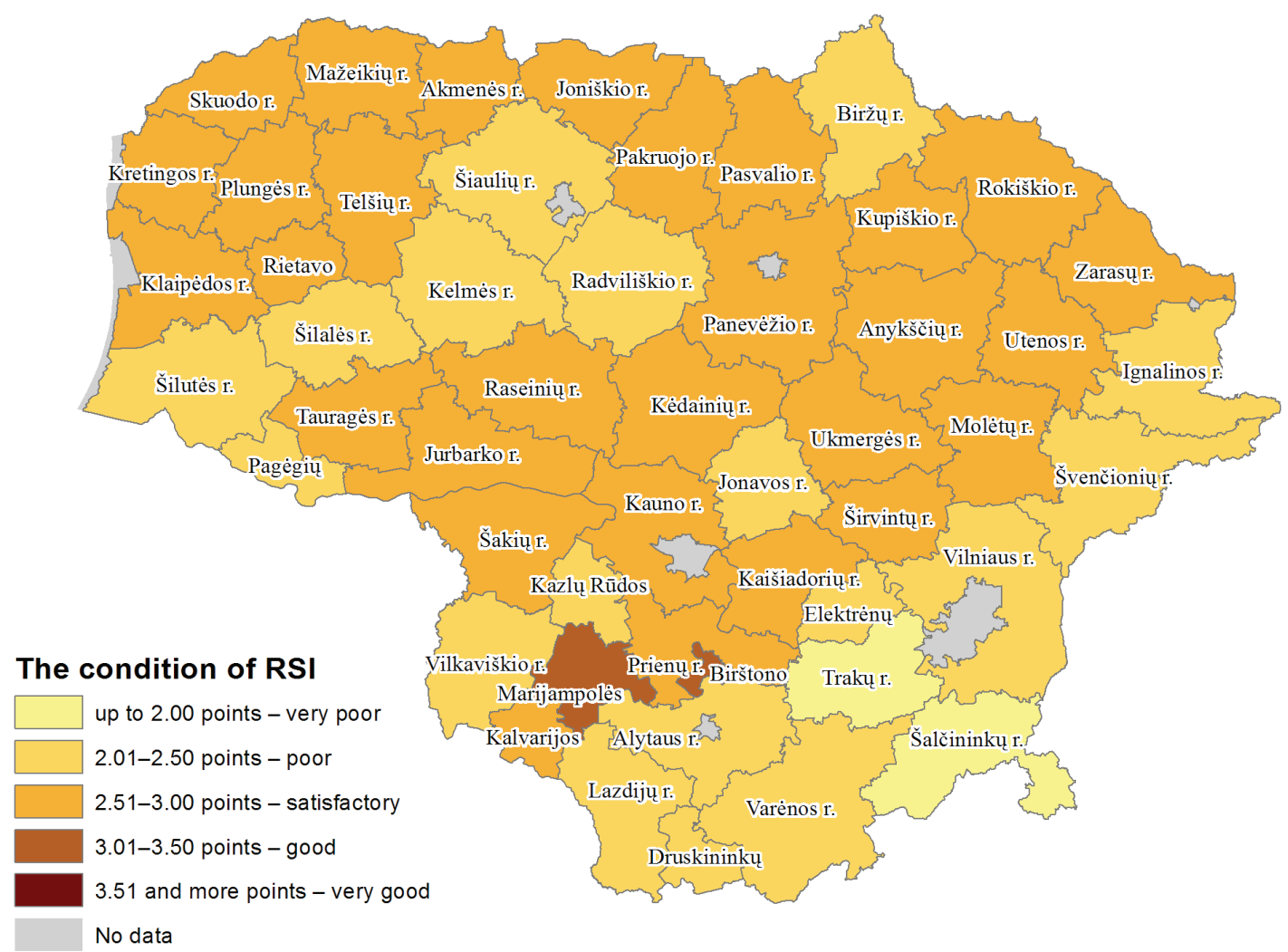

Fig. 2. Distribution of Lithuanian Municipalities by the average condition of the Rural Social Infrastructure, between 2008 and 2012

Source: the authors calculations 
More than half (56.86 per cent.), it is 29 Lithuanian districts and municipalities, RSI condition is evaluated as satisfactory and the evaluation score ranging from 2.93 to 2.51 points. These districts and municipalities group's average evaluation score is 5.43 percent higher than the national average and 13.57 percent higher than the districts and municipal groups which has a very bad average rank. RSI condition is evaluated as bad in 18 or 35.29 percent of all districts and municipalities (Table 2). The worst RSI is developed in Šalčininkai and Trakai districts - the average evaluation score - 1.89. Šalčininkai district RSI has the lowest evaluation in the country -1.79 points (51 place) and Birštonas municipality has the best ranking -3.08 points (1 place). A good RSI position is not only in Birštonas municipality, but also in Marijampole district (2 place) (Fig. 2).

The development of Birštonas municipality RSI average evaluation score is 19.38 percent, Marijampole district is 18.61 percent higher than Lithuanian average in districts. Vilnius district KSI condition evaluation score is 10.85 percent lower than in the average in the country and 25.32 percent lower in comparison with Birštonas municipality which has the best RSI condition in the country.

In conclusion it can be said that in individual districts and municipalities in Lithuania RSI is developed differently and that creates preconditions for social territorial cohesion problems which occur within the country.

Districts with underdeveloped RSI becomes less attractive to settle down and live in such areas, there are seeing a higher unemployment, lower disposable household income, certain groups of the population are forced to get to the corner of the society, as well as sustainable development of the country's regions is limited. The lack of RSI development creates surrounding which does not encourage, non-activating and reduces the efficiency of the total RSI, in rural areas of economic and social development of the negative impact on the district and has an effect on the region and the country's development.

\section{Conclusions}

During the analysis of literary sources have delivered the following RSI description: RSI is a territorial and spatial system of interrelated economic and social activities and relations, forming particular conditions for functioning of ecosystems, creation of human, physical and social capital to be used by individuals and society in order to fulfil individual and social needs. RSI is being created and developed by the society, individuals, businessmen, public and non-governmental institutions in order to ensure rural and urban integration, social and territorial cohesion.

In order to ensure social territorial cohesion, different assessment of RSI conditions was identified by eight sectors: education, training, counselling; telecommunications; utilities and household services; transport; culture, sport and recreation; trade and catering services; health and social care and personal and property protection. For each sector a certain number of indicators are assigned: 47 indicators until expert assessment, 30 indicators after expert assessment.

According to the results of expert evaluation it can be assumed that the data, which reflects the complexity of the recent situation in Lithuania and reveals sensitive problems of rural development, have been identified as very significant by experts. Later, however, during RSI assessment of the status, some very significant indicators were dropped according to deficiency of statistical data in the municipal level.

Municipalities with underdeveloped RSI become less desirable to live in, are characterized by higher unemployment, lower household income, residents being driven out of the society, and limited sustainable regional development. RSI sector limitations give rise to an environment which is non-encouraging, nonstimulating and reduces the overall RSI effectiveness and eco-social development of the particular area as well as negatively affects the development of the district, the entire region and the country. 


\section{References}

Atkociuniene, V. (2014). The Development of Rural Social Infrastructure Based on Community Needs. Proceedings of the 2014 International Conference "Economic science for rural development", No. 36, p. 165-172. Jelgava.

Atkociuniene, V., Kiausiene I., Urmoniene, D. (2014). The Innovative Management Principles of Rural Social Infrastructure Development. European Scientific Journal, Vol. 10, No. 7, p. 100-117.

Atkociuniene, V. (2008). Consistent Patterns of Rural Community Development. Community Development - a European Challenge, Verlag Barbara Budrich, p. 147-179.

Atkočiūnienė, V. (2000). Lietuvos kaimo socialinè infrastruktūra: ekonominis vertinimas ir plètra [Lithuanian Rural social Infrastructure: Economic Evaluation and Development, in Lithuanian]. Daktaro disertacija, socialiniai mokslai, ekonomika, LZUU, Akademija, 189 p.

Barca, F. (2009). An agenda for a reformed cohesion policy - a place-based approach to meeting European Union challenges and expectations. Independent report prepared at the request of Danuta Hübner, commissioner for regional policy. European Commission Regional Policy - Inforegio, p. 9-36. Available at http://ec.europa.eu/regional_policy/policy/future/pdf/report_barca_v0306.pdf.

CEC. (2010). Conclusions of the fifth report on economic, social and territorial cohesion: the future of cohesion policy. Communication from the Commission to the European Parliament, the Council, the European Economic and Social Committee, the Committee of the Regions and the European Investment Bank, COM (2010) 642 final, 9.11.2010. Brussels: COM, p. 7-10.

CEC. (2008). Green paper on territorial cohesion - turning territorial diversity into strength. Communication from the Commission to the Council, the European Parliament, the Committee of the Regions and the European Economic and Social Committee, COM (2008) 616 final, 6.10.2008. Brussels: COM, p. 1-13.

EEA. (2010). The territorial dimension of environmental sustainability - potential territorial indicators to support the environmental dimension of territorial cohesion. European Environmental Agency Technical Report, No. 9, p.7-17, $22-46$.

EU. (2007). Treaty of Lisbon amending the Treaty on European Union and the Treaty establishing the European Community, signed at Lisbon, 13 December, 2007. Official Journal of the European Union, Vol. 50(C306/01), p. 47.

Faludi, A. (2004). Territorial cohesion: old (French) wine in new bottles? Urban Studies, Vol. 41, No. 7, p. 1349-1365.

Faludi, A. (2009). Territorial cohesion under the looking glass, Synthesis paper about the history of the concept and policy background to territorial cohesion. European Commission Regional Policy -Inforegio, p. 1-24. Available at http://ec.europa.eu/regional_policy/consultation/terco/pdf/lookingglass.pdf

Faludi, A. (2013). Territorial Cohesion and Subsidiarity under the European Union Treaties: A Critique of the 'Territorialism' Underlying. Regional Studies, Vol. 47, No. 47, p. 1594-1606. Available at http://www.tandfonline.com/doi/ pdf $/ 10.1080 / 00343404.2012 .657170$

Flora, C. B., Flora, J. L. (1993). Entrepreneurial social infrastructure: a necessary ingredient. The Annals of the American academy of Political and Social Sciences, Vol. 529, No. 1, p. 48-58.

Gareth, A. (2014). What "Is" Territorial Cohesion? What Does It "Do"?: Essentialist Versus Pragmatic Approaches to Using Concepts. European Planning Studies, Vol. 22, No. 10, p. 2134-2155. Available at http://www.tandfonline. com/doi/pdf/10.1080/09654313.2013.819838

Hübner, D. (2007). Žalioji knyga dèl teritorinès sanglaudos. Kaip teritorinę įvairovę paversti privalumu [The Green Paper on Territorial Cohesion. Turning Territorial Diversity into Strength, in Lithuanian]. Inforegio panorama, No. 28. Available at http://ec.europa.eu/regional_policy/sources/docgener/panorama/pdf/mag28/mag28_lt.pdf

Loris, S. (2010). Planning Territorial Cohesion Discourses: Hegemonic Strategic Concepts in European Spatial Planning. Theory \& Practice, Vol. 11, No. 3, p. 397-416. Available at http:/www.tandfonline.com/doi/pdf/10.1080/146 49357.2010.500135 [2015-03-11].

Péti, M. (2012). A territorial understanding of sustainability in public development. Environmental Impact Assessment Review, Vol. 32, No. 1, p. 61-73.

Sharp, J. S., Agnitsch, K., Ryan, V., Flora, J. (2002). Social infrastructure and community economic development strategies: the case of self-development and industrial recruitment in rural Iowa. Journal of Rural Studies, Vol. 18, No. 4, p. $405-417$.

Swanson, L. E. (1992). Rural Social Infrastructure. In: J. N. Reid, D. Sears, G. Nelson, T. J. Rowley, M. Yetley (eds.). Foundations of Rural Development Policy, Boulder, CO, Westview Press.

Swanson, L. E. (1996). Social Infrastructure and Economic Development. In: T. D. Rowley, D. W. Sears, G. L. Nelson, J. N. Reid, M. J. Yetley (eds.). Rural Development Research: a Foundation for Policy. Westport, CT, Greenwood Perss, p. 103-119.

Žitkus, L., Mickevičienè, M. (2013). Konkurencingumas kaip regiono plètros siekinys. [Competitiveness as Objective of Regional Development, in Lithuanian]. Public policy and administration, Vol. 12, No. 3, p. 430-441. 


\section{TERITORINES SANGLAUDOS STIPRINIMAS PLÉTOJANT KAIMO SOCIALINE IN F RASTRUKT ÜRA}

Vilma AtKočiunienĖ, Alvydas AleksandravičIus, Gunta Grinberga-Zalite

Aleksandro Stulginskio Universitetas (Lietuva), Latvijos žemès ūkio universitetas (Latvija)

Santrauka

Ekonominiai ir socialiniai rodikliai yra reikšmingi kaimo socialinès infrastruktūros valdyme, vykdant šalies vystymosi stebėseną. Tyrimu siekta parengti kaimo socialinės infrastruktūros būklès vertinimo bandomają metodiką, siekiant stiprinti teritorinę sanglaudą. Spręsti šie uždaviniai: 1) apibendrinti kaimo socialinès infrastruktūros vystymosi atsižvelgiant ị teritorinę sanglaudą teorinius aspektus; 2) parengti kaimo socialinès infrastruktūros būklès vertinimo bandomąją metodiką; 3) nustatyti kaimo socialinès infrastruktūros vystymo Lietuvoje teritorinius skirtumus. Lietuvos kaimo socialinės infrastruktūros būklès vertinimas atskleidè kaimo socialinès infrastruktūros vystymo skirtumus, kurie daro neigiamą įtaką Lietuvos regionų konkurencingumui ir teritorinei sanglaudai. Nors straipsnyje pažymima, kad pastaraisiais metais vykdant investicinius projektus pasiekta tam tikrų teigiamų pokyčių, tačiau kaimo socialinès infrastruktūros prieinamumas ir pasiekiamumas vertinant pagal atskiras vietoves ir sektorius nèra optimalus.

PAGRINDINIAI ŽODŽIAI: kaimo socialinè infrastruktūra, kaimo vietovés, teritoriné sanglauda.

JEL KLASIFIKACIJA: H410, O330, R530, R590. 